\title{
НЕЙРОПСИХОЛОГІЧНА КОРЕКЦІЯ ОСНОВНИХ ФОРМ ДЕВІАНТНОЇ ПОВЕДІНКИ
}

Удк: 159.95

\section{Ткач Богдан Миколайович}

Кандидат психологічних наук, докторант лабораторії психологї̈ навчання ім. I. О. Синичі Інституту психології ім. Г.С. Костюка Національної академії педагогічних наук Украӥни, м. Київ (Украӥна)

\begin{abstract}
Анотація. $\quad$ статті представлено загальні підходи та особливості нейропсихологічної корекції основних форм девіантної поведінки. Висвітлено первинний, вторинний та третинний симптомокомплекси, які притаманні всім формам девіантної поведінки. Показано специфіку нейропсихологічної корекції агресивності при посттравматичному стресовому розладі та без нього. Рекомендовано використовувати персоноцентричний підхід до корекиії сексуальних девіацій з урахуванням ціннісно-нормативних стандартів суспільства. Запропоновано випереджальну тактику при корекиії суїидальної поведінки. Доведено, щุо при корекції адиктивної поведінки доцільно здійснювати повернення критичності особистості шляхом пригнічення автоматизованих механізмів запуску адиктивних дій та подолання патологічного гомеостазу в мозку.
\end{abstract}

Ключові слова: агресивна поведінка, сексуальні девіацї, суйщцдальна поведінка, адиктивна поведінка, нейропсихологічна корекція, дисфункиії мозку.

Постановка проблеми. Через дина- психологічних програм корекції основних мізм часу, трансформаційні процеси в суспі- форм девіантної поведінки у вітчизняній псильстві та збройний конфлікт на сході України хології. Існуючі у нашій країні нейропсихолодевіантна поведінка стає все більш актуальною і вимагає пошуку ефективних підходів для іiї профілактики та корекції. Існуючі методи не забезпечують бажаного результату, що зумовлює актуальність нашого дослідження. гічні корекційно-розвиваючі програми для дошкільнят і школярів молодших класів абсолютно непридатні для нейропсихологічної корекції сформованого девіантного мозку.

Натомість у світі активно розвивається

Аналіз останніх досліджень та публікацій показав недостатнє розроблення нейронейропсихологічна корекція із застосуванням технології зворотного зв'язку нейроінтерфей- 
са при ментальних тренінгах (медитації) [4; 9]. На базі інституту «Розум і життя», який спеціалізувався на вивченні медитативних наук, у 2000 році був започаткований проект «Медитативна нейробіологія». До цього проекту були залучені провідні майстри медитації тибетського буддизму та нейропсихологи, неврологи, нейробіологи 20-ти університетів [5; 10]. Багатолітній результат їхньої спільної науково-дослідної роботи довів цілющість медитативних технік при соматичних та психічних порушеннях. У західній цивілізації відбулася сертифікація світських медитативних технік, як терапевтичних методів, та масове впровадження їх практично у всіх сферах людської діяльності, починаючи від психотерапії у клініках, завершуючи підготовкою військових та поліцейських. Ефективність медитації еквівалентна фармакотерапії. Проте механізми зцілення різні [9].

В Україні також були спроби запровадження медитативних технік для нейропсихокорекції поведінки девіантів. Зокрема, у 2005 році була розроблена і впроваджена комплексна програма психопрофілактики основних форм адиктивної поведінки та підтримання психосоматичного здоров’я молоді «Образ власного Я» (Б.М. Ткач. Свідоцтво про реєстрацію авторського права на твір № 14536). Програма містила розроблену аналітичну медитацію «Почути себе та один одного». Проте, через домінування у суспільстві авраамічного і соціалістичного світорозуміння довелося ме- дитативні техніки використати як допоміжний елемент. Зараз у нашій країні існують аматорські центри медитацій, які не займаються нейропсихологічною корекцією.

Виділення невирішених раніше частин загальної проблеми. Здебільшого сучасні дослідження психологічних особливостей осіб 3 девіантною зводяться до побудови «інтегрального профілю девіантної особистості» на основі сумування всіх психічних феноменів, що притаманні девіантам. Ні практичної, ні наукової цінності такий «усереднений портрет» девіанта немає, адже в кожної особистості неповторна структура девіантності і застосовувати монокаузальний підхід некоректно. До того ж різні форми девіантної поведінки мають відмінну етіологію та симптоматику. 3 огляду на це, необхідно розкрити загальні підходи, методи та специфіку в нейропсихологічній корекції основних форм девіантної поведінки: агресивної поведінки, сексуальних девіацій, суїцидальної поведінки та адиктивної поведінки.

Метою статті $\epsilon$ висвітлення загальних принципів і методів нейропсихологічної корекції девіантної поведінки та специфіки корекції основних її форм.

\section{Виклад основного матеріалу і резуль-} татів дослідження. Для того щоб розробити програму нейропсихологічної корекції особистості $з$ девіантною поведінкою ми спочатку здійснили вивчення нейропсихологічних особливостей девіантів. У результаті нейропсихо- 
діагностики когнітивних порушень шляхом виключення альтернатив у 400 осіб з типовими для нашого суспільства девіаціями (з рівномірним гендерним розподілом і віком від 18 до 55 років) виявили чотири синдромологічні ядра девіантних особистостей та сформували три компоненти симптомокомплексу психічної стадії девіацій.

Первинний симптомокомплекс був представлений чотирма нейроперсонологічними типами, пов'язаних 3 мінімальними дисфункціями: орбіто-фронтальної частини префронтальної кори мозку (дОФПФк); дорсолатеральної частини префронтальної кори мозку (дДЛПФк); передньої цингулярної кори мозку (дПЦк); вентромедіальної частини префронтальної кори мозку (дВМПФк). Для осіб з проявами дОФПФк мозку характерним були: інфантильність; імпульсивність; емоційна лабільність; гедоністична мотивація; моральна агнозія; моральна апраксія; пошукова активність; схильність до ризику. Для осіб з проявами дДЛПФк мозку характерним були: слабовольність, конформізм, сугестивність, наслідуваність, простодушність, наївність, знижена увага. Для осіб з проявами дПЦк мозку характерним були: антиципаційна некомпетентність, ригідність, застрягання на певному виді діяльності/емоції чи особистості/ квазіособистості, прогностична нездатність, інтелектуальна слабкість, консерватизм. Для осіб з проявами дВМПФк мозку характерним були: харизматичність, відсутність совісті, ві- дсутність емпатії, хороші інтелектуальні здібності.

Вторинний симптомокомплекс представлений наслідками перебування людини під впливом наївного реалізму, домінуванням евристичного мислення і невмінням користуватися експертним мисленням у повсякденному житті; низькою комунікативною компетентністю; дезадаптацією через нездатність вчасно побачити альтернативні шляхи вирішення проблеми. Власне, вторинний симтомокомплекс у певному соціальному контексті обставин стає безпосередньою причиною формування девіацій. Виявлено, що вибір форми девіантної поведінки не є стохастичним процесом, а залежить від соціального походження, ціннісно-нормативних стандартів, матеріальних можливостей та інформаційного оточення. Було помічено певну тенденцію у вподобаннях різних девіацій. Зокрема, для осіб 3 дДЛПФк характерні девіації прийнятні/ традиційні для суспільства/групи; для осіб 3 дОФПФк притаманні девіації, які є неприйнятними і носять конфліктний характер для суспільства; для осіб з дВМПФк притаманним $€$ декларація однієї поведінки, а жити по діаметрально протилежній - девіантній; особи 3 дПЦк $є$ найбільш нерозбірливими i «зацикленими» на певних девіаціях. Було виявлено безпосередній зв'язок між низькою фрустраційною толерантністю і атарактивною мотивацією. Функціональний стан гіпокампа визначає, якою буде мотивація. Атарактивна 
мотивація притаманна особам із зниженою його функцією, а гедоністична - нормальною та підвищеною функцією.

Третинний симптомокомплекс - це, власне, і $є$ адикція: патологічний гомеостаз (постійне прагнення отримувати насолоду), а девіантні дії втрачають усвідомлений компонент і стають автоматизованим процесом.

Також нами було здійснено нейропсиходіагностику агресивності при посттравматичному стресовому розладі у 50 ветеранів АТО (з першої і другої ліній оборони). У процесі дослідження було виявлено у ветеранів порушення формування часової перспективи, зникнення відчуття звичної плинності часу, зниження здатності планувати діяльність.

Крім того ми застосували передові наукоємні нейротехнологігії -тривалий ЕЕГ моніторинг (мобільний нейроінтерфейс) у повсякденному житті девіантів, щоб дослідити особливості ЕЕГ появи девіантних дій при реальній соціальній взаємодії, а не в лабораторії. Було виявлено, що у різні періоди дня людина по-різному реагує на девіантні подразники i, відповідно, у неї різна мотивація. У першу половину (пік ранком) - це атарактивна мотивація, у другу половину дня (пік ввечері) - це гедоністична, а протягом робочого дня (два піки до обіду і після обіду) домінує афіліативна мотивація. Також було виявлено значимі відмінності у мотиваційній сфері між нейроперсонологічними типами девіантних особистостей. Виявилося, що рівень загальної актив- ності мозку визначає тенденцію девіації. Особи із зниженим рівнем активності мозку шукають психостимулюючу діяльність/субстанцію, особи із підвищеною - заспокійливу. Для осіб 3 девіацією характерним є домінування правої півкулі, а в момент перед реалізацією девіантної (думок) дії активізується ліва півкуля мозку.

На основі аналізу ЕЕГ відмінностей по когнітивних та емоційних показниках серед досліджуваних груп ми сформували гіпотезу, що ЕЕГ тренінги покращать якість повсякденного життя девіантам. Зокрема, для групи осіб 3 дВМПФк - «альфа тренінг»; для групи 3 дОФПФк - «бета/тета тренінг»; для групи 3 дДЛПФк - «альфа/тета тренінг»; групи 3 дПЦк, - «альфа тренінг» та «бета/тета тренінг». Для нормалізації міжпівкульної асиметрії мозку та руйнації нейронних мереж, пов'язаних із завченим компонентом дезадаптивної поведінки, вирішили перевірити які саме медитації є найбільш ефективними для кожного нейроперсонологічного типу девіантної особистості.

Все вище згадане дозволило нам сформувати завдання для нейропсихокорекційної програми: позбавити девіантну особистість від «завченого» компоненту переконання, що лише зовнішні об'єкти і ситуації можуть приносити щастя, та виучених деструктивних моделей обробки інформації, які проявляються у когнітивній, афективній та поведінковій сфе- 
pax особистості; сформувати резильєнтність та вирішити проблему з дисфункціями префронтальної кори в девіантів; забезпечити, щоб відчуття щастя було усвідомленим, керованим, тривалим, зі всією гамою відтінків і щоб спосіб реалізації не суперечив сучасним ціннісно-нормативним стандартам конкретного суспільства.

Загалом запропонована нейропсихологічна корекція девіантної поведінки грунтується на градієнтній теорії організації вищих психічних функцій людини E. Goldberg (2002); генетико-моделюючому методі виховання С. Д. Максименка (2002), який передбачає інтенсифікацію процесу самоусвідомлення і самозміни; принципах А. М. Грись (2014) формування терапевтичних цілей залежно від Я-норми; критеріях Л. Ф. Крупельницької (2012) вибору адекватного методу клінікопсихологічної інтервенції; позитивній нейропсихології М. Е. P. Seligman (2016); розроблених нами директивних нейропсихологічних класифікацій девіантної поведінки (ієрархія універсалії у структурі девіантної поведінки)
[1-3; 7; 11].

Нейропсихокорекція складається 3 таких етапів: створити штучно ілюзію впевненості; виробити стійкість до невизначеності; підсилити слабкі ланки обробки негативної інформації; підсилити функції префронтальної кори.

Ілюзія впевненості створюється шляхом розради (вислухати, зрозуміти, підтримати...), враховуючи ментальні та культурні особливості людини. Для покращення нейрогенезу застосовуємо нейройогу, ходьбу та зміну способу життя. Вироблення стійкості до невизначеності здійснюємо шляхом техніки когнітивного конструювання (створення альтернативних оцінок, позитивне конструювання близького майбутнього).

Підсилення слабкої ланки обробки негативної інформації здійснюємо завдяки усвідомленій медитації, чим саме полегшуємо процес нейропластики. Проте, на сьогодні ще невідомі нейротехнології, які б значно покращили здатність гіпокампу обробляти психот-

Таблиия 1.

Зміна когнітивних та емоційних показників до застосування програми і після

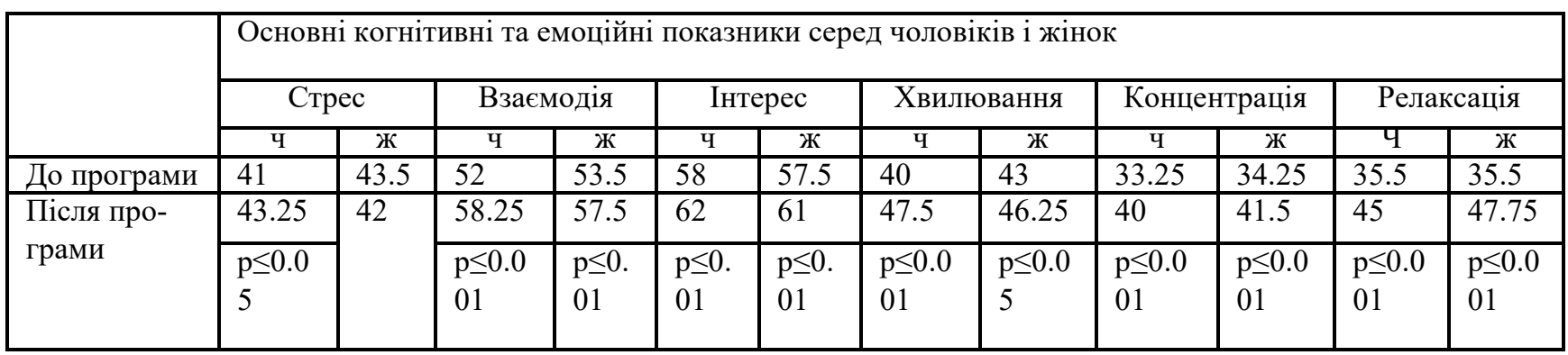


равмуючу інформацію. Тому ми пішли шляхом фрагментації психотравмуючої інформації на два потоки та іï трансформації для обробки одночасно двома півкулями, а не лише правою. Білатеральна обробка інформації дозволила нам швидше подолати «патологічний гомеостаз» у мозку пацієнта. При розгляді нейропсихокорекції агресивної поведінки буде детальніше висвітлено терапевтичні цілі і методи які застосовуються у програмі.

Оскільки у психокорекційній програмі одним із пріоритетних завдань було підвищити активність у лівій півкулі мозку, що характерно для щасливих людей, ми програму назвали «Щастя». Перевірка ефективності комплексної програми нейропсихологічної корекції проводилася нами протягом 2 місяців на групі з 20 чоловіків і 20 жінок віком 30-40 років $з$ різними формами девіантної поведінки. Застосування ЕЕГ дослідження та проективних методик показало достовірне зниження рівня тривожності та підвищення усвідомленості перебігу когнітивних процесів (табл. 1). Суб'єктивно досліджувані зазначають про те, що щоденна медитативна практика покращує якість нічного сну, дає відчуття безмежного i розслабленого щастя, яке дозволяє більш ясно сприймати людей і ситуації, а також зберігати цей стан незалежно від життєвих обставин. Девіантна поведінка стала керованою.

Під час апробації програми застосували бригадну модель надання комплексної психологічної допомоги. Очолює бригаду нейропси- холог, який здійснює нейропсихологічну діагностику і виявляє сильні сторони вищих психічних функцій для компенсації ослабленої. Залучає до бригади необхідних фахівців залежно від випадку (психологи, терапевт, невролог, психіатр). На основі всебічного обстеження складається індивідуальний план клінікопсихологічної інтервенції і кожен фахівець бригади отримував конкретне завдання. Здійснюється поточний та остаточний контроль ефективності нейропсихокорекції.

Надзвичайно хороших результатів нейропсихологічна корекція дає при використанні досягнень хронобіології. Адже освітлення відіграє колосальну роль для психічного стану та перебігу когнітивних процесів. Первинний осцилятор в людському організмі є супрахіазматиичні ядра гіпоталамуса, визначають кількість виділяння адреналіну, кортизолу. Активність цих ядер залежить від освітлення сітківки. Вторинний осцилятор у людини є епіфіз, який синтезує мелатонін.

Якщо людина «сова» (пізно лягає спати), ми рекомендуємо в першій половині дня максимально бути надворі (навіть у похмуру погоду освітлення в чотири рази інтенсивніше, ніж у супермаркеті), а з другої половини дня до вечора носити сонцезахисні окуляри. Якщо «жайворонок» (рано прокидається) рекомендуємо носити сонцезахисні окуляри в першій половині дня, а в другій максимально бути надворі. У тих, у кого катаракта, не рекомендуємо носити сонцезахисні окуляри, а по- 
силювати штучно освітлення приладами відповідно від того чи «сови» чи «жайворонки».

Девіантна поведінка - це об'єднання поведінкових розладів, які не $є$ гомогенною групою, ані за етіологією, ані за симптоматикою, лише спільним для них є те, що вони $є$ неприйнятними у суспільстві. Тому необхідно висвітлити специфіку нейропсихологічної корекції основних іiі форм: агресивної поведінки, сексуальних девіацій, суїцидальної поведінки та адиктивної поведінки.

Перейдемо до розгляду нейропсихокрекції агресивної поведінки. Первинну агресію до п’ятирічного віку розглядаємо як протоагpeciю через відсутність компоненту критичності в діях дітей. Адже під агресією розуміють будь-яку форму свідомої чи імітативної поведінки, скеровану на образу чи нанесення шкоди іншій особі, яка не бажає подібного ставлення до себе.

Ми розробили директивну нейропсихологічну класифікацію агресивності, в якій агресивність постає як первинний, вторинний та третинний компонент симптомокомплексу. Агресивна поведінка як первинний дефект уражееня префронтальної кори (розлад особистості органічного походження) спричинена порушенням функції програмування, регуляції та контролю психічної діяльності [6; 7].

Дисфункція орбіто-фронтальної частини префронтальної кори (диссоціальний розлад особистості; синдром дефіциту уваги $з$ гіперактивністю). Таким особам необхідно навчитися утримувати увагу на перебігу власних психічних процесів та актуалізувати самообмеження. У їхній побут долучити діяльність, яка тренує увагу і виробляє навик вчасності та доцільності дії (Йога, східні бойові мистецтва, теніс, метання предметів), розвиток стійкості уваги (картинки «знайди відмінності», лабіринти, пазли...), формування стриманості (запровадження правила «полічи до 10 перш, ніж діяти»). Акцент робити на медитаціях «Зосередження» («Концентрація увагиґ).

Дисфункція вентро-медіальної частини префронтальної кори (нарцисичний розлад особисті). Таким особам необхідно повернути Его та совість, сформувати усвідомленість власних емоцій та почуттів інших людей, розвивати емпатію. Практикувати медитацію на «Співпереживання» («Милосердя»), робота 3 обличчями людей по фотографіях (коміксах)/ фільмах (мультиках), гра на зображення емоційних станів та їх розпізнавання, рольові ігри 3 відображенням фрустраційних ситуацій та побути в ролі як «агресора», так і «жертви», написання творів про емоції, малювання та ліплення емоційних облич, нормалізувати завищену самооцінку.

Дисфункція дорсолатеральної частини префронтальної кори (гіпобулія; фанатизм; синдром деріциту уваги). Особам з цим розладом необхідно підвищити самооцінку, самосвідомість, довіру до самого себе та позитивне 
сприйняття власного образу «Я». Найкраще для цього підходить вправи для підсилення позитиву в Я-концепції: «карта успіху» (колова діаграма 3 різними сферами діяльності особистості); «щоденник успіху», залучення до гуртків. Практикувати медитацію на «Усвідомлення».

\section{Дисфункція}

латеральної (конвекситальної) частини префронтальної кори. Показана діяльність для зменшення довільності в руховій сфері (Йога, медитація на пропріорецепцію, формування «свідомої карта тіла», яка представлена у неокортексі), трансформація деструктивних дій у вербальну площину (правило «зупинись і подумай, що саме ти хочеш зробити і поміркуй чи є в цьому доцільність»).

Дисфункція передньої цингулярної кори (набутий психопатологічний тип особиcmocmi). Осіб з цим розладом необхідно навчити усвідомлювати появу власного гніву, розширити репертуар поведінкових реакцій, розвинути емпатію та нюансів у проявах емоцій. Для цього найкраще підходить медитація на «Присутність» (споглядання за всім оточуючим, за інтрапсихічною активністю, за тілесними процесами: дихання, серцебиття), «Співпереживання» («Милосердя»), робота над мімікою перед дзеркалом, аналіз емоцій інших людей, долати емоційне застрявання (інертність) на проблемній ситуації.

Ураження мигдалин - двобічне ураження скроневих ділянок (атараксія; синд- ром Клювера-Бьюсі). Необхідно лікувати причину (нейроінфекції, паразити, травми, метаболічні порушення), яка призвела до ураження, а також сформувати критичність до довільних дій і власного безстрашшя.

Агресивність, як вторинний дефект ураження, проявляється ворожою атрибуці$\boldsymbol{\epsilon}$ (оцінка ситуації та подій як ворожих). У дітей ситуація критична, оскільки порушення, у нижче розташованих структурах, викликає розлади вище розташованих. Називається цей феномен «ефект каскаду». У дорослих ворожа атрибуція виступає індикатором невирішеної важливої проблеми чи невдоволення якоїсь життєвої потреби, реакція на авторитарний стиль виховання, гіперопіку, гіпоопіку (відчуття покинутості), нереалізованих потреб у любові і визнанні. Причина може бути в оточуючих (сім'я, шкільний колектив, референтна група, суспільство). Також причиною є гностичні, мнестичні розлади, недостатності інтелекту, недостатності комунікативних навичок, дезадаптації, соматичні захворювання [3].

Особливої уваги заслуговує функціональний стан гіпокампу. Осіб, у яких функція гіпокампу нормальна або дещо підвищена, варто навчити оцінювати всі прояви власної агресивності, підсилити почуття провини у випадку цілеспрямованої агресії на інших, навчити брати на себе відповідальність за свої вчинки, підвищити емпатійність (медитація на «Співпереживання»), сформувати навички соціальної компетенції (розширити репертуар 
вирішення проблемних ситуацій; надати знання соціальних ролей та їх моделей поведінки). Дуже дієвими є розстановки по Хеллінгеру.

Натомість ті, у кого функція гіпокампу знижена, необхідно зменшити надмірну чутливість негативного ставлення до себе, здійснити емоційну десенсибілізацію до сприйняття ситуацій як ворожих щодо себе, побороти установку на те, що інші мають лише ворожі наміри, розвинути усвідомленість всього спектру своїх емоцій та контроль над ними. Для цього найкраще підходять Йога (релаксаційні техніки: м'язова релаксація, глибоке дихання, візуальні образи), медитації, робота зі страхами (вербалізація страхів), рольові ігри та розстановки по Хеллінгеру.

Агресивність, як третинний симптомокомплекс, долається завдяки зменшенню активності центру задоволення, налагодженню зв'язку між префронтальною корою та прилеглим ядром. Ця терапевтична задача досягається за допомогою формування мисленнєвої культури і критичного внутрішнього мовлення. Найголовнішим є розірвати сформовані зв'язки між проявом агресії і відчуттями задоволення, домінантності, власної значимості тощо. Це досягається за допомогою використання комплексної медитації («Безоб’єктна, Усвідомлення, Зосередження, Співпереживання»), коли короткотривале (ситуативне) відчуття щастя від агресії заміщається тривалим відчуттям стану щастя (зсув активності з правої півкулі мозку в ліву).
Зараз характерною є епідемія агресивності при посттравматичному стресовому розладі, яка характерна для постраждалих учасників антитерористичної операції та від військових дій на сході України, що тривають 3 2014 року. Психіка людей, яка була змінена відповідно до умов війни (інструментальна агресія), часто стає непристосованою до мирного життя, до «звичних» ціннісно-моральних стандартів суспільства. Зустрічаються випадки, коли флешбеки, нічні жахи, загострене почуття справедливості, агресивність, девіантність ветеранів спричиняють дискомфорт i страждання навіть для люблячих їх рідних та близьких. Підсилюючими чинниками психічної травматизації є каліцтва та соматичні хвороби, набуті під час війни. Як добре відомо, невирішені зараз психологічні проблеми у ветеранів згодом проявляться у них девіантною поведінкою та антисоціальними настроями. Зовсім неефективними виявилися світські медитації на співчуття до «страждань уявної істоти», тоді як дуже ефективними є медитації на власному болі та пережитих трагічних моментах. Для ветеранів надзвичайно важливим $€$ актуалізація моделі майбутнього в мирному житті, яка можлива при сприйнятті соціального часу, сформованій часовій перспективі та нормальному психофізіологічному часі.

На основі нейропсихологічного аналізу ми припускаємо, що гіперактивація правої півкулі інгібує передньо-асоціативні відділи лівої півкулі мозку, а також слабкість гіпокампу 
і гіперактивність мигдалин призводять до порушення формування часової перспективи $\mathrm{i}$ зникнення відчуття звичної плинності часу у ветеранів. Тоді як хороша орієнтація у просторі дозволяе формуванню часової перспективи на основі просторового гнозису, а повернення соціального часу стає першим кроком до ресоціалізації. Зчасовлення мови та корекція когнітивних спотворень досягаються завдяки збереженій здатності розуміння складних логікограматичних конструкцій. Знижена здатності планування діяльності в часі має вторинний характер і легко коректується тренінгом по тайм-менеджменту.

Перейдемо до розгляду корекції сексуальних девіації. Українці ведуть досить активне сексуальне життя і сексуальні девіації посідають провідне місце у бутті нашого суспільства. Сфера людської сексуальності є надзвичайно делікатною і потребує хороших знань 3 філософії, культурології, соціальної психології, нейропсихології, психіатрії, ендокринології, урології, гінекології та андрології. Освіта i світогляд особистості, а також культура і законодавство суспільства, визначає тактику психологічної корекції сексуальних девіацій. Крім того, у кожної людини свій унікальний шлях входження в сексуальне життя і не існує стандартів «як має бути». Тому спочатку треба дати відповіді, що саме у культурі є девіантним від істинної людської природи сексуальності. Після того, як поставили діагноз суспільству, можна переходити до розгляду поведі- нки особистості, яку в суспільстві трактують як девіантну у сфері сексуальності.

Наступним кроком є оцінка того, яку реальну шкоду завдає ця поведінка суспільству, оточенню особистості та самій особистості. Якщо нема некоректного сексуального поводження з іншими, нема невротизації і знайдений компроміс між індивідуальними сексуальними уподобаннями і суспільними вимогами, то втручання ні якого не потрібно. Лише здійснити прогноз чи в майбутньому ця поведінка не трансформується у девіантну. Гострота розладу визначає, чи буде це невідкладна чи планова сексологічна допомога.

Якщо наявна сексуальна девіація спричиняє незручності/страждання для особистості, групи чи суспільства, то необхідно визначити причину: набута (завчений компонент), вимушена (обставини контексту), психологічна проблема (в собі, в іншій особі...), соматична проблема, дисфункція мозку (нейропсиходіагностика симптомокомплексів). Зрозуміло, що від причини створюєте адекватну індивідуальну програму клінікопсихологічної інтервенції.

Корекція суїцидальної поведінки. Невідомими до кінця є причини, через які пересічна людина в певний момент буття стає потенційним суїцидентом. Суїцидальна поведінка - це дуже специфічна девіація, яка потребує випереджаючих дій психолога. Невміння швидко розпізнати суїцидальний процес i швидко його зупинити зводить нанівець ефек- 
тивність терапії, у даному випадку попередження суїциду [8; 12].

Суїцидальна поведінка в осіб без психіатричної патології виникає, коли психотравмуючі чинники виявляються сильнішими, ніж захисні механізми. Нейропсихологічною основою суїцидальної поведінки є: дисфункція вентральної, гіперфункція дорзолатеральної та гіпофункція орбітофронтальної частин префронтальної кори; гіперактивність неокортиксу правої півкулі мозку. Нейрохімічними особливостями суїцидального мозку є зниження серотонінергічної активності мозку загалом та більш висока активність серотонінових рецепторів у лівій орбітальній корі мозку. Це призводить до депресії, відчуженого ставлення до свого тіла, підвищення больового порогу, ослаблення когнітивних функцій (візуальної та вербальної пам'яті, порушення зоровопросторової орієнтації, ослаблення оцінювальної функції, порушення уваги, ослаблення оперативної пам'яті, нездатності розпізнавати небезпечні ситуації і користатися своїм життєвим досвідом), збереження інтелекту та цілеспрямованості у поведінці, нездатності долати стрес. Появі суїцидальних думок, передує зміна активності блукаючого нерва - вісцеральний компонент суїциду (некомфортні відчуття у тілі).

У рамках біхевіористично-когнітивної терапії робота проводиться 3 тілом (психосоматика, тілесні відчуття; блукаючий нерв), 3 емоціями (гальмування деструктив- них емоцій; лімбічна система), 3 когнітивною сферою (робота з когнітивними упередженнями; префронтальна кора) і 3 поведінкою (посилення цілеспрямованості упорядкованості та усвідомленості дій). Це все прояви проблеми, з якими психотерапевт вчить клієнта працювати, а сама проблема полягає у внутрішньому конфлікті, в «самому Я» чи «Я з Ми». Причиною даного конфлікту є порушення когнітивних функцій через вищевказані нейрофізіологічні зміни в мозку.

Корекція адиктивної поведінки. Як ми знаємо, адикцій безліч, а нейронних механізмів кілька. Завданням $є$ повернути критичність, подолати патологічний гомеостаз та автоматизовані механізми запуску адиктивних дій. Як показав досвід, досягти цього важко. Найкраще одну адикцію замінювати на іншу, яка $є$ прийнятною для суспільства, або принаймні не чинить загрози. Обов'язково замислитися, а чи корекція цієї адикції не завдасть вам особисто психологічної чи фізичної шкоди. У девіантному суспільстві коректувати конвенціальні адикції, як свідчить світова практика, не варто.

Також не варто забувати про тілесні розлади. Для здорової людини вживання будь-якої психоактивної речовини немає потреби і до більшості з них виникає огида від запаху/смаку. Наприклад, особа з гастритом здебільшого курить. При вилікуванні гастриту людина сама кидає курити, бо запах цигарок для неї стає огидним. Натомість особи з аска- 
ридозом не вживають горілки, віски, не курять, а полюбляють вегетаріанську їжу і вино, ведуть активний спосіб життя (адикція бігом, адикція фітнесом) і при значних фізичних навантаженнях не потіють. Всі ці особливості поведінки зумовлені зміною метаболізму через присутність гельмінтів. Те саме можна сказати не лише про інвазії, а й про багато хронічних інфекцій, які міняють кардинально метаболізм і призводять до появи тривалого патологічного гомеостазу, який організмом сприймається вже як звичний, нормальний. Тому нема простих рішень, здавалося, на прості запити позбавити людину адикції. Кожен випадок потребує всебічного вивчення. Тому директивні підходи «заборонити», «позбавити» $\mathrm{i}$ «покарати», з позиції сучасних знань $є$ некоректним для корекції адиктивної поведінки. Спочатку треба встановити причину, здійснити нейропсихологічну діагностику і сформувати індивідуальний план нейрокорекції. Надвичайним протектором формуванню адикцій є сім'я та референтна група.

Висновки. Спільність нейропсихологічних механізмів формування девіантної поведінки дозволило розробити комплексну програму нейропсихологічної корекції «Щастя». При емпіричному дослідженні виокремленні три симптомокомплекси у девіантних особистостей, які допомагають визначати психотерапевтичні цілі. Також встановлено, що первинний симптомокомплекс містить чотири синдромологічні ядра, пов'язані 3 мінімальними дисфункціями: орбіто-фронтальної частини префронтальної кори мозку; дорсолатеральної частини префронтальної кори мозку; передньої цингулярної кори мозку; вентромедіальної частини префронтальної кори мозку. Доведено ефективність корекції первинного симтомокомплексу за допомогою спеціально підібраних світських медитацій. Показано, що вторинний симтомокомплекс спричинений мнестичними, когнітивними порушення і у певному соціальному контексті обставин стає безпосередньою причиною формування девіацій. Коректується він шляхом підсилення ослабленого нейропсихологічного фактору, а також підвищенням мислиннєвої культури. Показано, що третинний симптомокомплекс - це сукупність проявів внаслідок автоматизації процесу реалізації девіантних дій та проявів патологічного гомеостазу. Корекція третинного симптомокомплексу полягає у поверненні критичності та подоланні патологічного гомеостазу.

Рекомендовано для забезпечення високої ефективності нейропсихокорекції девіацій застосовувати досягнення хронобіології та нейрогарнітури для ментальних тренінгів.

Не зважаючи на подібність, кожна 3 форм девіантної поведінки має свою етіологію та специфіку проявів і вимагає індивідуального підходу. Найкращим у цій ситуації є комплексний та системний підхід, який забезпечується застосуванням бригадної моделі надання нейропсихологічної допомоги. 


\section{Перспективи подальших досліджень.}

Розробка для масового застосування ефективних програм нейропсихокорекції особистості 3 девіантною поведінкою.

\section{Перелік використаних джерел:}

1. Грись А. М. Образ Я та механізми психологічного захисту як мішені психотерапевтичного впливу / А.М. Грись // Актуальні проблеми психології. Соціальна психологія. Збірник наукових праць Інституту психології імені Г.С. Костюка НАПН України, 2013. №6 (1), - С. 219-227.

2. Крупельницька Л. Ф. Метатеоретичне мислення психотерапевта: модель, дослідження, програма розвитку / Л.Ф. Крупельницька. - Київ: Геопринт, 2012. - 283с.

3. Максименко С. Д. Розвиток психіки в онтогенезі: Теоретико-методологічні проблеми генетичної психології (Т.1) / С.Д. Максименко. - Київ: Ваклер, 2002. - 319с.

4. Chapin T. J., Russell-Chapin L.A. Neurotherapy and Neurofeedback: Brain-Based Treatment for Psychological and Behavioral Problems / T.J. Chapin, L.A. RussellChapin. - New York: Routledge, 2013. - 232p.

5. Davidson R. J., Begley S. The Emotional Life of Your Brain: How Its Unique Patterns Affect the Way You Think, Feel, and Live - and How You Can Change Them / R.J. Davidson, S. Begley. - New York: Hudson Street Press, 2012. -304 p.

6. Foster H. G., Hillbrand M., Silverstein M. Neuropsychological deficit and aggressive behavior: a prospective study. Foster H.G., Hillbrand M., Silverstein M. / H.G. Foster, M. Hillbrand, M. Silverstein // Prog Neuropsychopharmacol Biol Psychiatry, 1993. - N17(6). - P. 939-946.

7. Goldberg E. The Executive Brain: Frontal Lobes and the Civilized Mind / E. Goldberg. - New York: Oxford University Press, 2002. - 251p.

8. Griffiths J. J., Zarate C.A., Rasimas J.J. Existing and novel biological therapeutics in suicide prevention / J.J. Griffiths, C.A. Zarate, J.J. Rasimas // Am J Prev Med,
2014. - N 7(3 Suppl 2), - P. 195-203.

9. Penman D., Burch, V. Mindfulness for Health: A Practical Guide to Relieving Pain, Reducing Stress and Restoring Wellbeing / D. Penman, V. Burch. - London: Little, Brown Book Group, 2013. - 289p.

10. Rinpoche Y. M. \& Tworkov H. Turning Confusion into Clarity: A Guide to the Foundation Practices of Tibetan Buddhism / Y.M. Rinpoche, H. Tworkov, - Boston \& London: Slow Lion, 2014. - 416 p.

11. Seligman M. E. P. Authentic Happiness: Using the New Positive Psychology to Realize Your Potential for Lasting Fulfillment / M.E.P Seligman. - New York: Atria Books, 2004. - 336p.

12. White J., Marsh I., Kral M.J., Morris J. Critical Suicidology: Transforming Suicide Research and Prevention for the 21st Century / J. White, I. Marsh, M.J. Kral, J. Morris (Eds.). Vancouver, Toronto: UBC Press, 2017. - 283p.

\section{References (Transliteration):}

1. Hrys A. M. Obraz Ya ta mekhanizmy psykholohichnoho zakhystu yak misheni psykhoterapevtychnoho vplyvu / A.M. Hrys // Aktualni problemy psykholohii. Sotsialna psykholohiia. Zbirnyk naukovykh prats Instytutu psykholohii imeni H.S. Kostiuka NAPN Ukrainy, 2013. №6 (1), - S. 219-227.

2. Krupelnytska L. F. Metateoretychne myslennia psykhoterapevta: model, doslidzhennia, prohrama rozvytku / L.F. Krupelnytska. - Kyiv: Heoprynt, 2012. 283s.

3. Maksymenko S. D. Rozvytok psykhiky v ontohenezi: Teoretyko-metodolohichni problemy henetychnoi psykholohii (T.1) / S.D. Maksymenko. - Kyiv: Vakler, 2002. -319 s.

4. Chapin T. J., Russell-Chapin L.A. Neurotherapy and Neurofeedback: Brain-Based Treatment for Psychological and Behavioral Problems / T.J. Chapin, L.A. RussellChapin. - New York: Routledge, 2013. - 232p.

5. Davidson R. J., Begley S. The Emotional Life of Your Brain: How Its Unique Patterns Affect the Way You Think, 
Feel, and Live - and How You Can Change Them / R.J. Davidson, S. Begley. - New York: Hudson Street Press, 2012. -304 p.

6. Foster H. G., Hillbrand M., Silverstein M. Neuropsychological deficit and aggressive behavior: a prospective study. Foster H.G., Hillbrand M., Silverstein M. / H.G. Foster, M. Hillbrand, M. Silverstein // Prog Neuropsychopharmacol Biol Psychiatry, 1993. - N17(6). - P. 939-946.

7. Goldberg E. The Executive Brain: Frontal Lobes and the Civilized Mind / E. Goldberg. - New York: Oxford University Press, 2002. - $251 \mathrm{p}$.

8. Griffiths $J$.J., Zarate C.A., Rasimas J.J. Existing and novel biological therapeutics in suicide prevention / J.J. Griffiths, C.A. Zarate, J.J. Rasimas // Am J Prev Med, 2014. - N 7(3 Suppl 2), - P. 195-203.

9. Penman D., Burch, V. Mindfulness for Health: A Practical Guide to Relieving Pain, Reducing Stress and Restoring Wellbeing / D. Penman, V. Burch. - London: Little, Brown Book Group, 2013. - 289 p.

10. Rinpoche Y. M. \& Tworkov H. Turning Confusion into Clarity: A Guide to the Foundation Practices of Tibetan Buddhism / Y.M. Rinpoche, H. Tworkov, - Boston \& London: Slow Lion, 2014. - 416 p.

11. Seligman M. E. P. Authentic Happiness: Using the New Positive Psychology to Realize Your Potential for Lasting Fulfillment / M.E.P Seligman. - New York: Atria Books, 2004. -336 p.

12. White J., Marsh I., Kral M.J., Morris J. Critical Suicidology: Transforming Suicide Research and Prevention for the 21st Century / J. White, I. Marsh, M.J. Kral, J. Morris (Eds.). Vancouver, Toronto: UBC Press, 2017. -283 p.

\section{Tkach Bohdan}

PhD in Psychology, Doctoral student of I. O. Sinitsy Laboratory of Educational Psychology of H. S. Kostyuk Institute of Psychology of the National Academy of Educational Sciences of Ukraine, Kyiv (Ukraine)

\section{THE PRINCIPLES OF NEUROPSYCHOLOGICAL CORRECTION OF THE MAIN FORMS OF THE DEVIANT BEHAVIOUR}

\section{ABSTRACT}

The article presents general approaches and peculiarities of neuropsychological correction of the main forms of the deviant behaviour. The initial, secondary and tertiary symptom complexes, which are characteristic of all forms of the deviant behaviour, are outlined. It is stated that the initial symptom complex is caused by dysfunctions in programming, regulating and controlling the mental activity resulting from prefrontal cortex damage. The methods of neuropsychological correction of different symptomological nuclei of the initial symptom complex are suggested. It is discovered that the secondary damage defect is recognized by the hostile attribution, which results from gnostic and mnemonic disorders, low intelligence, lack of communicative skills, disadaptation and somatic disorders. The methods of neuropsychological correction of the symptoms of the secondary defect are presented. It is pointed out that the tertiary symptom complex with a negative compensatory rearrangement is formed according to the principles of pathological homeostasis and constant desire to derive satisfaction. It is suggested to reduce activity of the pleasure centre using techniques of establishing connection between prefrontal cortex and the adjacent nucleus. The characteristic aspects of neuropsychological correction of aggression displayed by 
people with or without posttraumatic stress disorder are singled out. It is suggested to apply an anthropocentric approach to correction of sexual deviances with regard to the system of values and norms of the society. It is specified that neuropsychological basis of suicidal behaviour is formed by: malfunction of the ventral, hyperfunction of the dorsolateral and hyperfuntion of the orbitofrontal parts of the prefrontal cortex, hyperfunction of the neocortex in the right hemisphere and reduction of the parahippocampal gyrus. Advanced strategy for suicidal behaviour correction is suggested. It is advised to recover critical thinking in the process of addictive behaviour correction by eliminating automated addictive action's launch mechanisms and by fighting pathological homeostasis of the brain.

Key words: aggressive behaviour, sexual deviances, suicidal behaviour, addictive behaviour, neuropsychological correction, brain malfunction.

\section{Ткач Богдан Николаевич}

Кандидат психологических наук, докторант лаборатории психологии обучения имени И. О. Синицьы Института психологии имени Г. С. Костюка Национальной академии педагогических наук Украинь, г. Киев (Украина)

\section{НЕЙРОПСИХОЛОГИЧЕСКАЯ КОРРЕК- ЦИЯ ОСНОВНЫХ ФОРМ ДЕВИАНТНО- ГО ПОВЕДЕНИЯ}

Аннотация. В статье представлены общие подходы и особенности нейропсихоло- гической коррекции основных форм девиантного поведения. Освещены первичный, вторичный и третичный симптомокомплексы, которые присущи всем формам девиантного поведения. Показана специфика нейропсихологической коррекции агрессивности при посттравматическом стрессовом расстройстве и без него. Рекомендуется использовать персоноцентричный подход к коррекции сексуальных девиаций с учетом ценностнонормативных стандартов общества. Предложено опережающую тактику при коррекции суицидального поведения. Доказано, что при коррекции аддиктивного поведения целесообразно осуществлять возврат критичности личности путем подавления автоматизированных механизмов запуска аддиктивных действий и преодоления патологического гомеостаза в мозге.

Ключевые слова: агрессивное поведение, сексуальные девиации, суицидальное поведение, аддиктивное поведение, нейропсихологическая коррекция, дисфункции мозга. 